\title{
Development and treatment of fresh lung carcinoma after successful lobectomy
}

\author{
R. A B B E Y S M I T H \\ From King Edward VII Chest Hospital, Hertford Hill, nr. Warwick
}

A close follow-up of all patients treated surgically for lung carcinoma has been carried out. The follow-up was designed to give as much information as possible on the cause of death following operation, particularly over the long term. During this study it became clear that many patients developed fresh evidence, primarily radiological, of lung carcinoma at varying times after operation. This appeared to be more frequent than the literature suggested and to be a problem of sufficient size to consider the possibility of further operative treatment in an attempt to arrest the progress of the disease. This and other aspects considered in this paper have already been fully discussed by Hughes and Blades (1961) in their report.

By concentrating principally on patients for whom further surgery seemed justifiable, much information on the natural history of other aspects of the disease after operation has probably been lost. This paper describes the different patterns of development of fresh carcinoma and adds information on the important matter of the development of fresh primary lung tumour or tumours, properly described by Le Gal and Bauer (1961) as a complication of successful lung cancer surgery.

It would be simpler to discuss only those patients thought to have developed further primary tumours. By including all the manifestations of extension it may be easier to form an opinion on the evidence put forward that a proportion of patients develop fresh primaries rather than metastases.

Chest radiographs at four-monthly intervals on every patient operated upon, from the date of operation to death, provide the basis for this study. When a fresh radiological shadow, presumably due to lung carcinoma, appeared, the origin of the shadow and its treatment comprise the clinical problems.
METHOD OF FOLLOW-UP

The following requirements were considered necessary for an adequate follow-up. The followup had to be complete, it had to include every patient, and it had to be personally carried out ; the patient had to be asked to travel a minimum distance, and radiographs had to be taken at least twice yearly to death.

In no case has the patient's private doctor been asked to state the cause of death, although help has been obtained in discovering why the patient failed to attend the follow-up clinic.

The actual method of follow-up (carried out from 1952 to the present time) is simple and traditional. At the time of operation the patient's name, the type of operation, and the date are entered in a central register. On discharge from hospital the patient is seen at one of seven clinics held each fortnight; the one nearest his home is chosen. At the clinic a radiograph is available at each visit, and at the time of the visit the patient's name is entered under a date two to six months ahead, depending on the time since operation, in a book held by the surgeon at the clinic. The advantages of this are twofold-the date of the next visit is registered as it is given to the patient, and it is independent of the normal hospital record system. If the patient fails to keep this appointment the date is carried forward two weeks in the clinic book ; if this fails, the patient's doctor is contacted. The information obtained at the peripheral clinic is entered in the central register, from which it can be readily seen if a patient has not been examined in any quarter of the current year. The failure of any patient to attend the clinic can be confirmed in a few moments. Deaths are removed from the current central register. Readmission to hospital for bronchoscopy, other investigation, or treatment is recommended when necessary. 
In a follow-up of this sort, we consider inconvenience to the patient to be negligible. It is estimated that a patient under follow-up from 1952 to 1965 has spent some 72 hours in 13 years in travelling to hospital, having radiographs taken, and being clinically examined. This method has given as complete information as it is possible to obtain from clinical examination, cytological examination of the sputum, and chest radiography on all but seven of the patients discharged from hospital after operation. Of these seven, five have moved from the area of personal follow-up; of these five, two have died from multiple metastases and three are alive and their radiological follow-up continues elsewhere. The remaining two are unwilling to attend. They are alive more than five years after operation and at irregular intervals have chest radiographs. They are visited in their homes by a health visitor.

It can be claimed that this follow-up is in one sense complete, although if a patient dies suddenly at home and necropsy is not carried out, the exact cause of death is unknown and freedom from carcinoma cannot be claimed, even though three months previously the clinical findings and chest radiographs were normal. It clearly demonstrates that the incidence of fresh carcinoma following this series of resections cannot be less, but could be greater, than in this report. One vital point must be stressed; in no patient have important fresh symptoms preceded a suspicious radiographic change, in other words, the first evidence of fresh carcinoma in these patients has always been radiological, and therefore it is a development which must be actively looked for if it is to be detected as soon as possible. Doubtless fresh symptoms will develop, but if the detection of a second primary lung tumour is left until gross symptoms arise, the glandular metastases from this second primary may so alter the clinical picture that a clear-cut difference between metastases from the original tumour and the development of a second primary no longer exists. The doctor without specialized knowledge or diagnostic aids will inevitably consider the patient's deterioration to be due to metastasis from the original tumour. It is for this reason that the patient's doctor never has been asked the cause of death for record purposes.

Patients whose chest radiographs show no abnormality after resection other than the effects of the operation, who subsequently show evidence of fresh carcinoma in the lung, and in whom this was the only manifestation of extension comprise the subjects. Emphasis is placed on the fact that this was the only manifestation, because it was in this ill-defined group that the possibility of further resection was considered. Excluded were all patients with radiological extension of disease known to have extrathoracic metastases, patients with widespread multiple contralateral shadows presumed to be due to metastases (two patients), and those with rapidly enlarging mediastinal glands, evidence of rib erosion or pleural effusion with local extension of tumour as the cause.

Although it is an unsatisfactory method of classifying the clinical material, the problem is presented in this way because the development of a radiological abnormality was the first sign of fresh carcinoma in the patients under discussion. Because of this, the analysis of the patients conveniently starts from this point.

\section{PATIENTS UNDER REVIEW}

From 1952 to April 1965, 650 resections were carried out-369 pneumonectomies, 269 lobectomies, and 12 segmental resections. The indications of opzrability were those suggested by Belcher and Anderson (1965). The entire group of 650 patients were followed up by the method described.

The pneumonectomy patients will not be discussed because of the rarity of fresh carcinoma appearing in the contralateral lung. Metachronous fresh primary tumours have appeared in the remaining lung in only four post-pneumonectomy patients to date, and we have never considered further surgery in a patient who has previously undergone pneumonectomy.

Lobectomy in our patients was carried out when this operation appeared to allow total removal of macroscopically involved lung and hilar glands. All these resections, therefore, were potentially curative. In spite of the high incidence of locally recurrent carcinoma and fresh primary carcinoma after lobectomy, the long-term results are acceptable. From the total of 269 lobectomies, 121 were carried out more than five years ago, and 42 of these lived for more than five years $(34.6 \%$ fiveyear survival). Four died in hospital $(3.2 \%$ operative mortality). Of the 12 segmental resections, three are free of evidence of recurrence more than four years after operation; one died six years after operation from coronary thrombosis and at necropsy no residual tumour was found throughout the body. One died five years after operation from extension of the tumour locally and to the brain. Four were operated upon a second time. The remaining three died within 18 months of operation from carcinomatosis. 
TA B LE I

ORIGIN OF RADIOLOGICAL EXTENSION OF TUMOUR FOLLOWING 269 LOBECTOMIES AND 12 SEGMENTAL

\begin{tabular}{|c|c|c|c|c|}
\hline \multicolumn{4}{|l|}{ Origin } & No. \\
\hline $\begin{array}{l}\text { Stump recurrence } \\
\text { Circumscribed extension of tumour } \\
\text { Localized mediastinal gland metast } \\
\text { Fresh primary lung tumour } \quad .\end{array}$ & in lung & $\begin{array}{l}\cdots \\
\cdots \\
\cdots\end{array}$ & $\begin{array}{l}\cdots \\
\cdots \\
\cdots\end{array}$ & $\begin{array}{r}6 \\
6 \\
7 \\
19\end{array}$ \\
\hline 37 males, 1 female (P12; Table V) & Total & .. & . & 38 \\
\hline
\end{tabular}

The radiological extensions of tumour that have occurred in this group of 269 lobectomies and 12 segmental resections in the years after operation are shown in Table I. In this group of 281 lobectomies and segmental resections, the first evidence of fresh tumour has been radiological, and the radiological lesion has been well circumscribed in 38 patients. These patients, after a complete clinical examination, survey of their radiographs, bronchoscopic examination, and retrospective examination of the findings at the first operation, have been classified under the main groups shown in Table I. The most difficult group to classify were those who, though at first sight thought to have developed a fresh lung primary, were found to have metastases in mediastinal glands with or without extension of tumour into the lung as the cause of the new radiological shadow. This group has been included because the possibility of further surgery existed, and it has been assessed by the same criteria as before the first operation.

STUMP RECURRENCE We define stump recurrence as a condition in which a biopsy positive for neoplasm is obtained from the stump of the transected lobar bronchus. It may occur early as part of a generalized spread of tumour. These patients are excluded. The term is perhaps a bad one. So-called stump recurrence may occur in patients in whom the original tumour was not visible at bronchoscopy, the line of transection was clear of tumour, and freedom from infiltration was confirmed by microscopy of the bronchus at the site of division. There is no reason why this condition, as described by Hughes and Blades (1961), could not arise from a fresh primary tumour in the bronchus at stump level.

Patients in whom stump recurrence was suspected by radiological change and confirmed by bronchoscopy are shown in Table II. At the outset the radiological change was the only evidence of extension, and re-operation, though considered in each patient, was not carried out in any patient.

A case history illustrates a number of features.

CASE S5 A man aged 57 had an anaplastic squamous-cell tumour removed in May 1957 by left upper lobectomy. Microscopic squamous-cell carcinoma was present in the bronchial mucosa at the line of section of the bronchus. After two years a biopsy from the stump revealed the same tumour. Re-operation was considered but was not performed. No treatment was given and the patient survived in good health for eight years after operation. The tumour finally encroached on and occluded the trachea ; the patient died of bronchopneumonia.

Progress in this patient was slow and illustrates that length of time cannot help in differentiating between growth of tumour deposits to a clinical level and the development of a fresh primary. It is perhaps important to note that a radiographic abnormality was present for the last five years of life. Clearly in this patient the origin of the fresh tumour was the growth of an established microscopic focus. Had this small focus been in the opposite lung it would have been attractive to consider it a fresh primary on the grounds of the time interval between the separate manifestations.

TA B LE II

STUMP RECURRENCE

\begin{tabular}{|c|c|c|c|c|c|c|c|c|}
\hline \multirow[b]{2}{*}{ Case } & \multirow[b]{2}{*}{ Age } & \multirow[b]{2}{*}{$\begin{array}{l}\text { Biopsy at } \\
\text { Bronchoscopy }\end{array}$} & \multirow[b]{2}{*}{$\begin{array}{l}\text { Operation } \\
\text { (date) }\end{array}$} & \multirow[b]{2}{*}{$\begin{array}{c}\text { Cell } \\
\text { Type }\end{array}$} & \multirow{2}{*}{$\begin{array}{c}\text { Hilar } \\
\text { Glands } \\
\text { Involved }\end{array}$} & \multicolumn{2}{|c|}{ Interval from Operation to: } & \multirow[b]{2}{*}{ Cause of Death } \\
\hline & & & & & & $\begin{array}{l}\text { Confirmation } \\
\text { of Stump Re- } \\
\text { currence (yrs.) }\end{array}$ & $\begin{array}{c}\text { Death } \\
\text { (yrs.) }\end{array}$ & \\
\hline S1 & 57 & Negative & L.L. lobectomy & Squamous & No & 3 & $4 \frac{1}{2}$ & Mediastinal extension of \\
\hline $\mathbf{S 2}$ & 70 & Negative & $\begin{array}{l}\text { R.L. lobectomy } \\
\text { (Dec. 1955) }\end{array}$ & Squamous & No & 4 & $5 \frac{1}{2}$ & $\begin{array}{l}\text { Tumour deposits in trachea; } \\
\text { tumour L.U.L. }\end{array}$ \\
\hline S3 & 46 & Negative & $\begin{array}{l}\text { L.L. lobectomy } \\
\text { (Aug. 1956) }\end{array}$ & Squamous & No & $3 \frac{1}{2}$ & 4 & $\begin{array}{l}\text { Malignant oesophago-tracheal } \\
\text { fistula }\end{array}$ \\
\hline S4 & 64 & Negative & R.U. lobectomy & Squamous & No & 3 & 5 & Mediastinal extension \\
\hline S5 & 57 & Positive & L.U. lobectomy & Squamous & No & 2 & 8 & Mediastinal extension \\
\hline S6 & 68 & Positive & $\begin{array}{l}\text { R.M. lobectomy, } \\
\text { R.L. lobectomy } \\
\text { (July 1960) }\end{array}$ & Squamous & Yes & 2 & 28 & Tumour deposits in trachea \\
\hline
\end{tabular}


TABLE III

CIRCUMSCRIBED EXTENSION OF TUMOUR IN LUNG

\begin{tabular}{|c|c|c|c|c|c|c|c|}
\hline Case & $\begin{array}{c}\text { Age at } \\
\text { First } \\
\text { Operation }\end{array}$ & $\begin{array}{l}\text { Reason for } \\
\text { Conservative } \\
\text { Resection }\end{array}$ & $\begin{array}{c}\text { Type of Segmental } \\
\text { Resection } \\
\text { (date) }\end{array}$ & $\begin{array}{l}\text { Cell } \\
\text { Type }\end{array}$ & $\begin{array}{l}\text { Type of Second } \\
\text { Operation } \\
\text { (date) }\end{array}$ & $\begin{array}{l}\text { Interval from } \\
\text { First Operation } \\
\text { to Death }\end{array}$ & Cause of Death \\
\hline C1 & 63 & $\begin{array}{l}\text { Mistaken } \\
\text { diagnosis }\end{array}$ & $\begin{array}{l}\text { Posterior segment } \\
\text { R.U. lcbe } \\
\text { (May 1954) }\end{array}$ & $\begin{array}{l}\text { Adeno- } \\
\text { carcinoma }\end{array}$ & $\begin{array}{l}\text { R. pneumonectomy } \\
\text { (July 1955) }\end{array}$ & 2 years & Mediastinal extension \\
\hline $\mathrm{C} 2$ & 58 & $\begin{array}{l}\text { Associated } \\
\text { pulmonary } \\
\text { tuberculosis }\end{array}$ & $\begin{array}{l}\text { A pical segment } \\
\text { R.L. lobe } \\
\text { (May 1957) }\end{array}$ & Squamous & None & 5 years & $\begin{array}{l}\text { Cerebral metastases, } \\
\text { no necropsy }\end{array}$ \\
\hline C3 & 70 & Age & $\begin{array}{l}\text { Apico-posterior } \\
\text { segment L.U.L. }\end{array}$ & $\begin{array}{l}\text { Adeno- } \\
\text { carcinoma }\end{array}$ & None & $2 \frac{1}{2}$ years & Mediastinal extension \\
\hline C4 & 49 & $\begin{array}{c}\text { Chronic } \\
\text { bronchitis }\end{array}$ & $\begin{array}{l}\text { Local excision } \\
\text { R.L. lobe } \\
\text { (Noy }\end{array}$ & Squamous & $\begin{array}{l}\text { R.L. lobectomy } \\
\text { (Oct. 1961) }\end{array}$ & $\begin{array}{l}\text { Alive; further } \\
\text { extension in lung }\end{array}$ & \\
\hline C5 & 60 & Small tumour & $\begin{array}{l}\text { Apical segment } \\
\text { R.L. lobe } \\
\text { (Dec. 1961) }\end{array}$ & $\begin{array}{l}\text { Adeno- } \\
\text { carcinoma }\end{array}$ & $\begin{array}{l}\text { R.M. lobectomy } \\
\text { and R.L. lobec- } \\
\text { tomy (May 1964) }\end{array}$ & Hospital death & $\begin{array}{l}\text { Pulmonary embolus; } \\
\text { no residual tumour } \\
\text { at necropsy }\end{array}$ \\
\hline C6 & 59 & Small tumour & $\begin{array}{l}\text { Apico-posterior } \\
\text { segment L.U. lobe } \\
\text { (Oct. 1962) }\end{array}$ & Squamous & $\begin{array}{l}\text { L. pneumonectomy } \\
\text { (July 1963) }\end{array}$ & 4 months & $\begin{array}{l}\text { Carcinomatosis; meta- } \\
\text { stasis in liver and kid- } \\
\text { neys at necropsy }\end{array}$ \\
\hline
\end{tabular}

CIRCUMSCRIBED EXTENSION OF TUMOUR IN LUNG Re-operation was carried out in four of six patients who developed a circumscribed extension of tumour. In the six patients, extension occurred after segmental resection, presumably due to incomplete excision by this method. The second operation produced no permanent beneficial effect on the spread of tumour in the four patients operated upon a second time (Table III), except possibly in patient $C 4$. It would seem illogical to re-operate on a patient who at assessment before the first operation was considered a fit subject only for segmental resection. It remains to be established that the difference in ultimate respiratory function between segmental resection and lobectomy practised for lung carcinoma is ever sufficient to justify segmental resection. Against this empirical rejection of segmental resection is the fact that five of our 12 cases of segmental resection survived more than four years after operation.

LOCALIZED MEDIASTINAL GLAND METASTASES Isolated enlargement of mediastinal glands, due to metastatic deposits producing radiological change on a previously normal radiographic appearance during follow-up, has been the first sign of fresh tumour in seven patients. It is an ill-defined group. Extension into a bronchus may or may not be present. A patient in this category is described.

CASE L1 A miner aged 64 at the time of right upper lobectomy in 1955 for a squamous-cell carcinoma (Fig. 1) progressed satisfactorily for five years. In 1960 he developed a shadow in the right upper zone, thought to be a second primary (Fig. 2). At bronchoscopy no tumour was visible. Re-operation was considered but rejected on the grounds of age and diminished respiratory reserve. The patient's condition deteriorated rapidly. Superior vena caval obstruction was not relieved by radiotherapy and he died six months after the development of the new shadow and nearly six years after lobectomy. At necropsy metastatic deposits from the original tumour were confined to the glands adjacent to the azygos vein. There were no involved contralateral mediastinal glands, no bronchial involvement, and no other evidence of tumour throughout the body. Bronchopneumonia was the cause of death.

In another of these seven patients, a fresh shadow appeared in the radiograph four and a half years after right lower lobectomy. Penetration of the oesophagus and the right main bronchus by extension from this localized glandular deposit of tumour led to an oesophago-bronchial fistula, which caused the patient's death. Necropsy confirmed this as the only evidence of recurrence throughout the body.

FRESH PRIMARY LUNG TUMOUR From the total of 269 lobectomies being followed up, a fresh tumour regarded as a fresh primary lung carcinoma has developed in 19 patients. Of these 19 patients. 12 have been operated upon a second time and $\mathrm{O}$ two of these 12 patients three times (Table IV).

Excluded from the series but mentioned to complete the statistics are one patient who developed on a fresh isolated tumour four years after lobectomy for an alveolar-cell carcinoma and three patients $N$ with what were considered bilateral synchronous $\mathrm{N}$ tumours at the time of diagnosis. For technical reasons none of these patients was operated upon, $\infty$ and for this reason they are excluded from further $\bar{D}$ study.

ESTABLISHMENT OF DIAGNOSIS OF SECOND PRIMARY $\frac{T^{\circ}}{\oplus}$ TUMOUR The suspicion that a lesion appearing $\stackrel{1}{9}$ in the patient's radiograph after operation is $\stackrel{\mathbb{D}}{2}$ malignant is generally correct. The origin and nature of this second lesion is an open question, $\Omega$ 


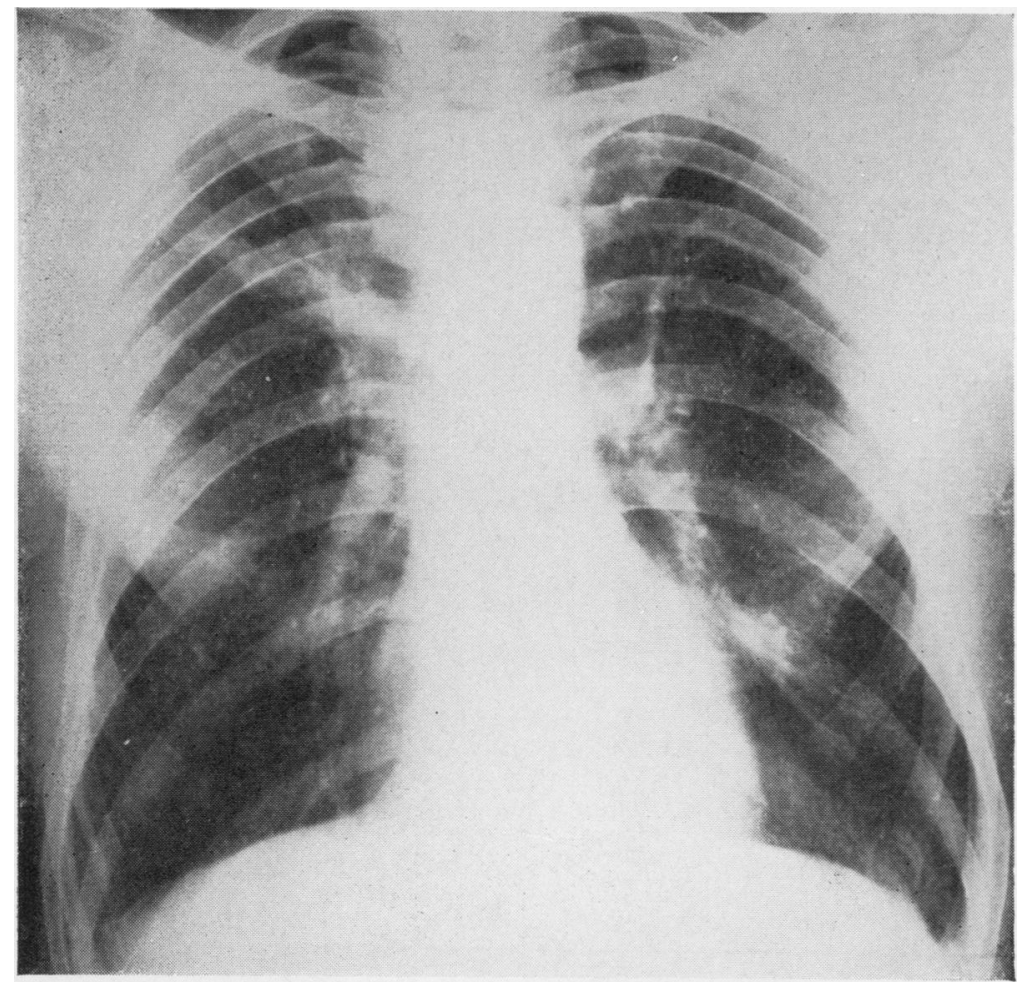

FIG. 1. Case L1, 1955. Right upper lobe tumour.

FIG. 2. Case L1, 1960. Localized mediastinal gland metastasis five years after right upper lobectomy.

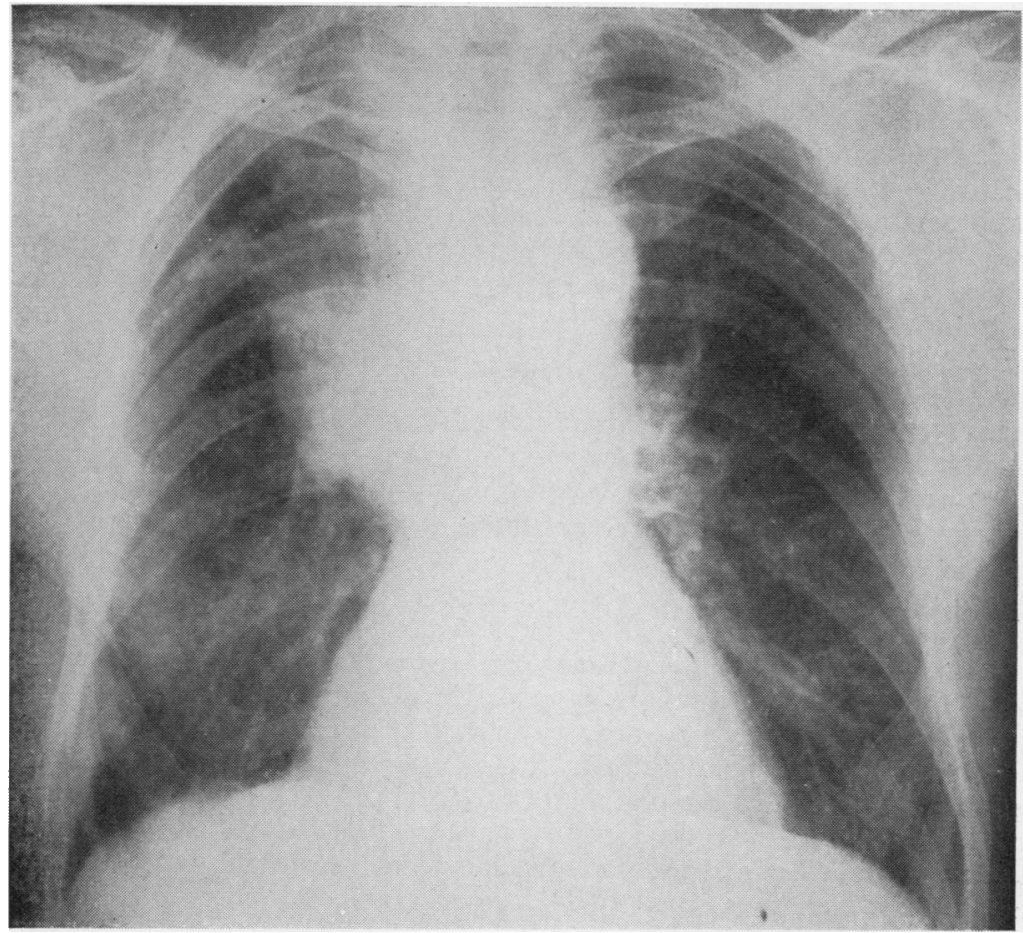


TABLE IV

FRESH LUNG PRIMARY: PATIENTS OPERATED UPON TWICE

\begin{tabular}{|c|c|c|c|c|c|c|c|c|c|c|}
\hline Case & $\begin{array}{l}\text { Age at } \\
\text { First } \\
\text { Oper- } \\
\text { ation }\end{array}$ & $\begin{array}{c}\text { Biopsy } \\
\text { Positive at } \\
\text { Bronchoscopy }\end{array}$ & Operation & $\begin{array}{c}\text { Hilar } \\
\text { Glands } \\
\text { In- } \\
\text { volved }\end{array}$ & $\begin{array}{c}\text { Interval } \\
\text { between } \\
\text { Opera- } \\
\text { tions } \\
\text { (months) }\end{array}$ & $\begin{array}{l}\text { Second } \\
\text { Operation }\end{array}$ & $\begin{array}{c}\text { Hilar } \\
\text { Glands } \\
\text { Involved }\end{array}$ & $\begin{array}{l}\text { Present } \\
\text { State }\end{array}$ & $\begin{array}{l}\text { Interval } \\
\text { since } \\
\text { Second } \\
\text { Operation } \\
\text { (months) }\end{array}$ & \\
\hline $\begin{array}{l}\text { P1 (Figs } \\
11 \text { and 12) }\end{array}$ & 57 & Never & R.U. lobectomy & No & 108 & L.L. lobec- & No & Alive & 14 & Free of recurrence \\
\hline $\begin{array}{l}\text { P2 (Figs } \\
13 \text { and 14) }\end{array}$ & 59 & $\begin{array}{l}\text { Before first } \\
\text { operation }\end{array}$ & $\begin{array}{l}\text { R.U. lobectomy } \\
\text { (sleeve) }\end{array}$ & No & 60 & L.L. lobec- & Yes & Alive & 3 & Free of recurrence \\
\hline $\begin{array}{l}\text { P3 (Figs } \\
15 \text { and 16) }\end{array}$ & 52 & $\begin{array}{c}\text { Before second } \\
\text { operation }\end{array}$ & R.L. lobectomy & No & 54 & $\begin{array}{l}\text { L.U. lobec- } \\
\text { tomy } \\
\text { (sleeve) }\end{array}$ & No & Dead & 30 & $\begin{array}{l}\text { Died of coronary } \\
\text { thrombosis; no } \\
\text { recurrence; no }\end{array}$ \\
\hline P4 & 66 & Never & L.U. lobectomy & Yes & 36 & L.L. lobec- & Yes & Alive & 2 & Free of recurrence \\
\hline P5 & 54 & $\begin{array}{l}\text { Before both } \\
\text { operations }\end{array}$ & L.U. lobectomy & No & 35 & $\begin{array}{l}\text { L.L. lobec- } \\
\text { tomy }\end{array}$ & Yes & Dead & 8 & $\begin{array}{l}\text { Necropsy, recur- } \\
\text { rence in stump and } \\
\mathbf{R} \text {. lung; no extra- } \\
\text { thoracic tumour }\end{array}$ \\
\hline P6 & 58 & $\begin{array}{r}\text { Before first } \\
\text { operation }\end{array}$ & $\begin{array}{l}\text { R.L. lobectomy } \\
\text { and R.M. } \\
\text { lobectomy }\end{array}$ & Yes & 30 & $\underset{\text { tomy }}{\text { R.U.lobec- }}$ & No & Alive & 5 & $\begin{array}{l}\text { Mediastinal recur- } \\
\text { rence }\end{array}$ \\
\hline P7 & 46 & $\begin{array}{c}\text { Before first } \\
\text { operation }\end{array}$ & $\begin{array}{l}\text { R.L. lobectomy } \\
\text { and R.M. } \\
\text { lobectomy }\end{array}$ & No & 29 & $\underset{\text { tomy }}{\text { L.L. lobec- }}$ & Yes & Dead & 11 & $\begin{array}{l}\text { Necropsy; recur- } \\
\text { rence in media- } \\
\text { stinal glands; } \\
\text { secondaries, both } \\
\text { kidneys }\end{array}$ \\
\hline P8 & 53 & Never & R.U. lobectomy & No & 17 & L.U. lobec- & No & Alive & 12 & $\begin{array}{l}\text { S.V.C. obstruction } \\
\text { from mediastinal } \\
\text { recurrence }\end{array}$ \\
\hline P9 & 51 & $\begin{array}{c}\text { Before first } \\
\text { operation }\end{array}$ & R.U. lobectomy & No & 16 & $\begin{array}{l}\text { L.U. lobec- } \\
\text { tomy } \\
\text { (seg.) }\end{array}$ & No & Dead & 22 & $\begin{array}{l}\text { Extension in L.U.L. } \\
\text { with local rib } \\
\text { erosion }\end{array}$ \\
\hline $\begin{array}{l}\text { P10 (Figs } \\
17 \text { to } 19)\end{array}$ & 52 & Never & L.U. lobectomy & No & 4 & $\begin{array}{l}\text { R.L. lobec- } \\
\text { tomy }\end{array}$ & No & Dead & 33 & $\begin{array}{l}\text { Developed third } \\
\text { primary; no } \\
\text { necropsy }\end{array}$ \\
\hline
\end{tabular}

moreover, it is a question which at the moment cannot be answered unequivocally. Considering this with the fact that the best available treatment for a fresh isolated lesion appears to be its removal might appear to make a discussion on whether the fresh lesion is a second primary carcinoma a meaningless gesture. Too many issues of practical importance are involved to pass this as an academic matter. Excluding the possibility that the original lesion and the fresh lesion represent metastases from elsewhere in the body (Payne, Clagett, and Harrison, 1962), the fresh lesion may arise by bronchial implantation of tumour fragments, or as lymphatic or blood-borne metastases, or may represent a second primary tumour. It is unnecessary to postulate that all arise in the same manner.

Bronchial implantation of tumour fragments is not a fashionable explanation. Fragments of tumour may be dislodged at biopsy, be implanted, and grow at varying rates. It is conceivable that mucosal damage during bronchoscopy might promote this, or that small tumour fragments may be inhaled and rest in the peripheral bronchi. The undamaged bronchial mucosa appears to be immune to the effects of sputum containing malignant cells, which must pass over a considerable area of mucosa during coughing. With actual fragments of tumour on damaged mucosa, the effects might be different. The presence of tumour deposits in the trachea of three patients (cases S2, $\mathrm{S} 6$, and $\mathrm{P} 12$ ) in this series is a finding to be explained. Direct mucosal infiltration was excluded in one patient and highly unlikely in the other two, so circumscribed were the tracheal lesions. The rarity of spontaneous tumours of the trachea is apparent, and the finding of isolated tracheal deposits at necropsy is equally so. Because of the possibility of tumour spread by bronchial implantation, we no longer biopsy or disturb the necrotic, proliferative, endobronchial carcinoma at bronchoscopy.

Lymphatic or blood-borne metastasis as a cause for the second lesion is not one we favour. The absence of lymph-gland involvement at the first or second operation makes retrograde lymphatic permeation unlikely. The possibility of bloodborne metastases by the bronchial circulation exists. We have encountered an isolated bloodborne metastasis to the brain as the only evidence of tumour throughout the body at necropsy in a patient four and a half years after lobectomy. If metastasis isolated to the brain can occur, there is no reason why it could not occur in the opposite 
lung as an isolated metastasis. Tumour-cell aggregates may lie dormant for years before presenting as recognizable tumours, but the rapidity with which the second lesion develops after a long latent interval seems to justify an assumption that this rate of growth is inherent in the second tumour from its inception. The hypothesis that a metastatic deposit may be present, yet radiologically invisible, for up to 10 years and abruptly grow to a tumour of significant proportions, is not easy to understand, although not exclusive.

Those interested in establishing the existence of multiple primary tumours in the lung have used different criteria. Robinson and Jackson (1958) quote Billroth (1879); Hughes and Blades (1961) state 'following pulmonary resection, carcinoma in the bronchial mucosa of other parts of the lung may represent the development of a new primary lesion'. Langston and Sherrick (1962), Glennie, Harvey, and Salama (1964), and Watson, Cameron, and Percy (1964) quote the criteria of earlier workers. Watson et al. (1964) in their review paraphrase Goetze's (1913) criteria as (1) the gross and microscopical appearances of the tumours must correspond to those of the usual primary carcinomas of the organs concerned; (2) the likelihood of one tumour being a metastasis from the other must be positively excluded so far as this is possible; (3) the diagnosis is supported by the presence of some known common predisposing factor or by each tumour producing its own metastases.

Payne et al. (1962) describe factors in favour of a pulmonary tumour being primary rather than metastatic. Although these factors were described to distinguish primary lung tumours from tumours in the lung secondary to carcinoma elsewhere in the body, equally they help in recognizing a second lung primary. Shields, Drake, and Sherrick (1964) regard the criteria of Warren and Gates (1932) as helpful but not final. The criteria as described are: each of the tumours must present a definite picture of malignancy; each must be distinct and the possibility of one being a metastasis of the other must be excluded. Shields et al. (1964) state with justification 'the last possibility is, of course, difficult to resolve'. Cliffton, das Gupta, and Pool (1964) considered only one of their three cases of second lung primary as being proved. In this patient the two tumours examined after removal were of different histology. Another patient had an interval of over 10 years between operations. These authors consider this time interval as suggestive of a second primary but not conclusive. Brock (1964) describes a patient with an interval of 15 years between right lower and left upper lobectomy for a fresh primary tumour.

Each of the papers quoted has influenced the classification of our 19 tumours as second lung primaries. The factors which lead us to believe that each fresh tumour is more likely to represent a second primary than anything else are these. It must have the clinical characteristics and radiological growth pattern of a primary lung tumour. Direct extension must be excluded and the possibility of metastasis from the lung primary or elsewhere must be excluded as thoroughly as possible from the findings at the first and subsequent operations. Both tumours must originate in bronchial mucosa but need not be of different microscopic appearances. They may or may not be synchronous. The findings at necropsy after the second operation should be consistent with the findings at necropsy after operation for a lung primary. Extensive lymph-gland involvement at the first operation and the appearance of the second lesion on the side of operation weigh against a diagnosis of a fresh primary. All lesions following segmental resection have been regarded as metastases, even though in case $\mathrm{C} 6$ the second tumour showed the pathological characteristics of a fresh primary, namely, growth from and along the mucosa.

Information on the point of origin of the second tumour from bronchial mucosa at microscopy is not complete, although in their gross characteristics these tumours appeared to originate from the mucosa. Inevitably, necropsy findings are not available for all patients. The most unusual multiple primary patient we have treated will be described.

CASE P11 (Table V) A heavy smoker, aged 59 at the time of right lower lobectomy for a squamous-cell tumour (Fig. 3) in June 1959, remained well until March 1962. Although symptomless, his radiograph showed a right middle lobe shadow (Fig. 4). A right middle lobectomy was successfully carried out in April 1962 ; microscopy confirmed that this tumour originated in the bronchial mucosa. He remained well and at work, but, without the development of any fresh symptoms, his radiograph showed a shadow in the left upper lobe (Fig. 5). In March 1964, a segmental resection of the left upper lobe was performed. Each of these three tumours was a poorlydifferentiated squamous-cell carcinoma. The radiographic appearances are shown in Figure 6.

The patient returned to work five weeks after this operation. He remained well for five months following this third resection. Abruptly, on getting out of bed one morning, he noted tinglings in both legs. Later the same day he was admitted to hospital, where 


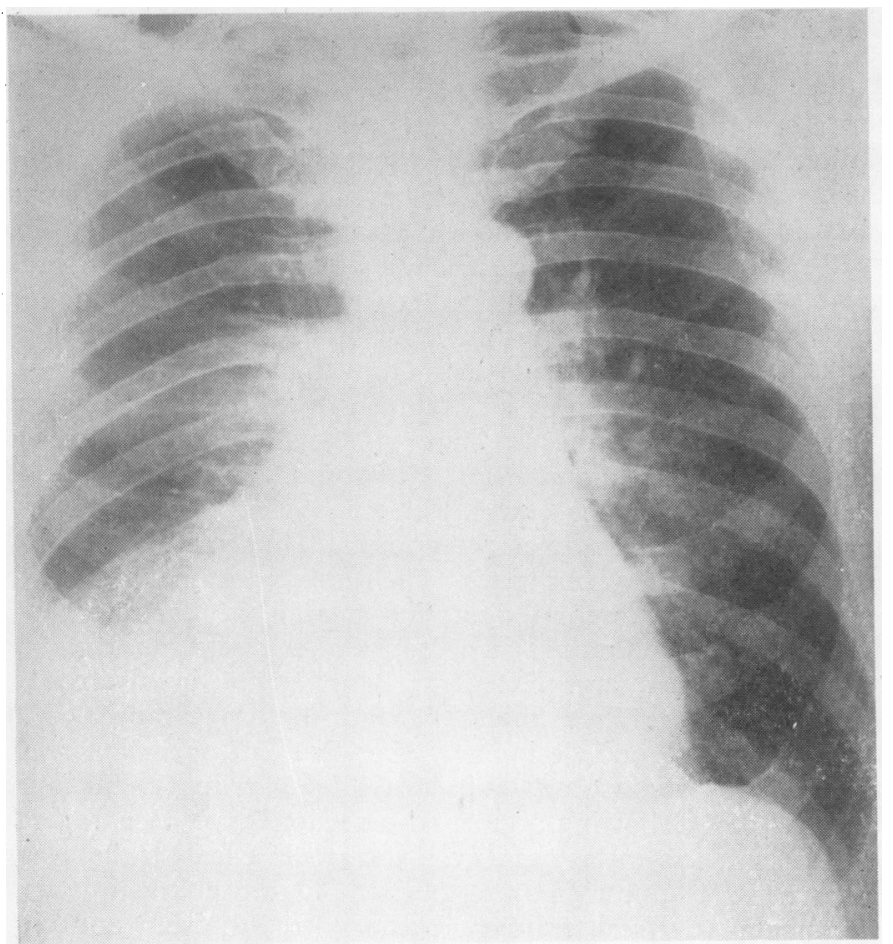

FIG. 3. Case P11, 1959 (Table V). Right $\stackrel{\overrightarrow{.}}{\vec{H}}$ lower lobe collapse due to tumour.

FIG. 4. Case P11, 1962. Fresh primary tumour right middle lobe.

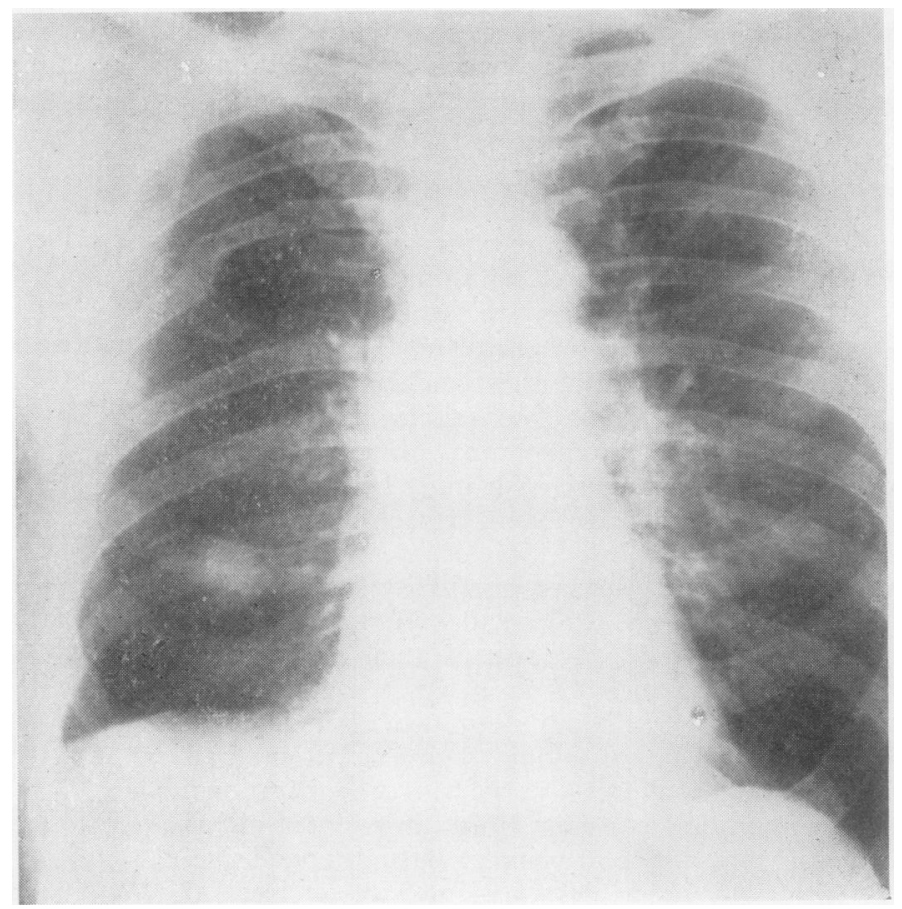




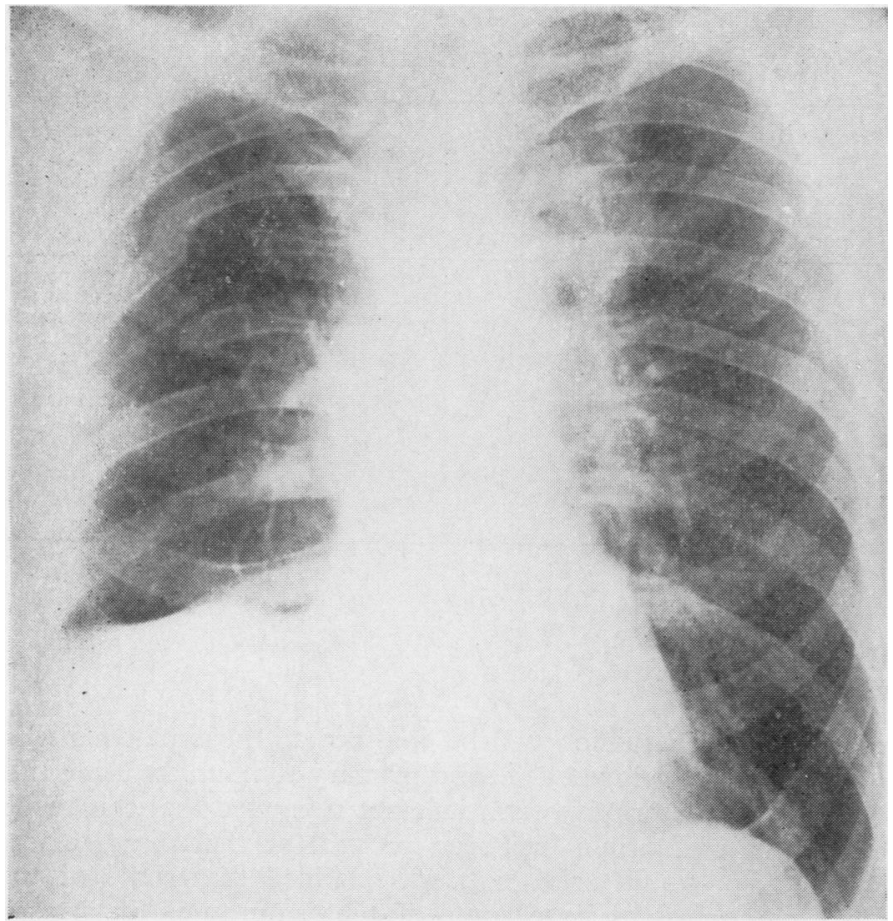

FIG. 5. Case P11, 1964. Fresh primary tumour left upper lobe.

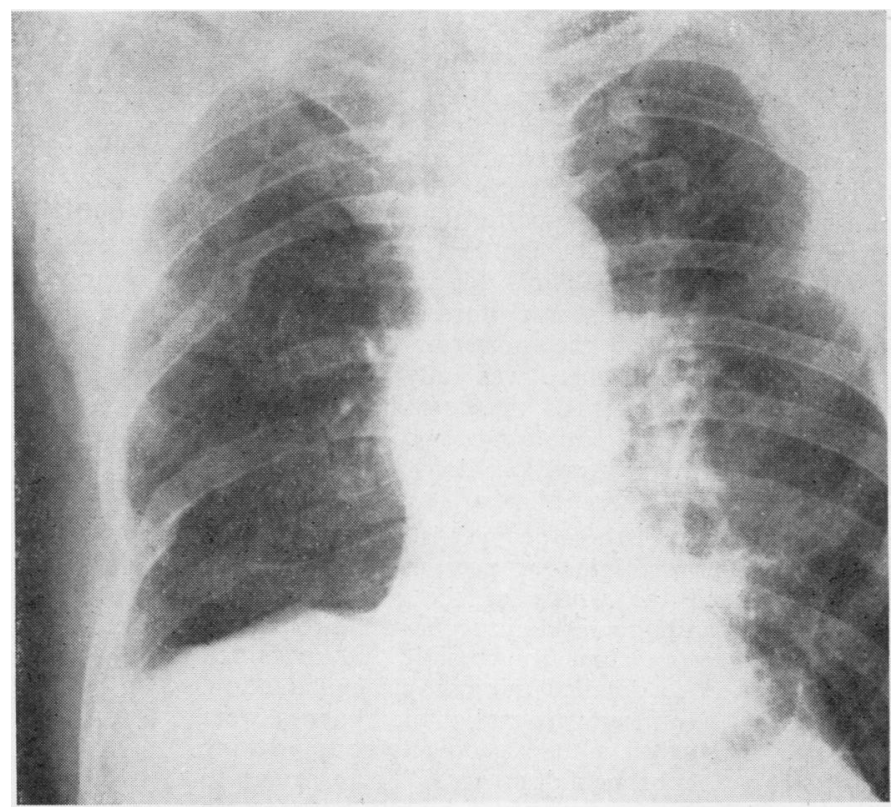

FIG. 6. Case P11, at time of return to work after third operation. 
TABLE V

FRESH LUNG PRIMARY: PATIENTS OPERATED UPON MORE THAN TWICE

\begin{tabular}{|c|c|c|c|c|c|c|c|c|c|c|}
\hline Case & $\begin{array}{l}\text { Age at } \\
\text { First } \\
\text { Opera- } \\
\text { tion }\end{array}$ & $\begin{array}{l}\text { Biopsy } \\
\text { Positive at } \\
\text { Broncho- } \\
\text { scopy }\end{array}$ & $\begin{array}{c}\text { Hilar } \\
\text { Glands } \\
\text { Involved }\end{array}$ & $\begin{array}{c}\text { Type } \\
\text { of First } \\
\text { Operation } \\
\text { (date) }\end{array}$ & $\begin{array}{c}\text { Interval } \\
\text { between } \\
\text { First and } \\
\text { Second } \\
\text { Operations } \\
\text { (months) }\end{array}$ & $\begin{array}{l}\text { Type of } \\
\text { Second } \\
\text { Operation } \\
\text { (date) }\end{array}$ & $\begin{array}{l}\text { Interval } \\
\text { between } \\
\text { Second } \\
\text { and Third } \\
\text { Operations } \\
\text { (months) }\end{array}$ & $\begin{array}{c}\text { Type of } \\
\text { Third } \\
\text { Operation } \\
\text { (date) }\end{array}$ & $\begin{array}{l}\text { Pre- } \\
\text { sent } \\
\text { State }\end{array}$ & Comment \\
\hline $\begin{array}{c}\text { P11 } \\
\text { (Pigs } \\
3 \text { to 6) }\end{array}$ & 59 & $\begin{array}{c}\text { Before first } \\
\text { operation }\end{array}$ & $\begin{array}{l}\text { Free of } \\
\text { meta- } \\
\text { stases } \\
\text { through- } \\
\text { out }\end{array}$ & $\begin{array}{l}\text { R.L. lobec- } \\
\text { tomy (June } \\
\text { 1959) }\end{array}$ & 34 & $\begin{array}{l}\text { R.M. lobec- } \\
\text { tomy (April } \\
\text { 1962) }\end{array}$ & 23 & $\begin{array}{l}\text { Apico- } \\
\text { posterior } \\
\text { segment } \\
\text { L.U. lobe } \\
\text { (March } \\
\text { 1964) }\end{array}$ & Dead & $\begin{array}{l}\text { Died of paraplegia; } \\
\text { cause uncertain; } \\
\text { microscopic fourth } \\
\text { primary present }\end{array}$ \\
\hline P12 & 50 & $\begin{array}{c}\text { Before first } \\
\text { and second } \\
\text { operations }\end{array}$ & $\begin{array}{l}\text { Free of } \\
\text { meta- } \\
\text { stases } \\
\text { through- } \\
\text { out }\end{array}$ & $\begin{array}{l}\text { L.U. lobec- } \\
\text { tomy } \\
\text { (sleeve) } \\
\text { (July } \\
\text { 1962) }\end{array}$ & 18 & $\begin{array}{l}\text { Local removal } \\
\text { of mid- } \\
\text { tracheal } \\
\text { tumour }+ \\
\text { DXR (Jan. } \\
\text { 1964) }\end{array}$ & & $\begin{array}{l}\text { Residual } \\
\text { left } \\
\text { pneumo- } \\
\text { nectomy } \\
\text { (Nov. } \\
\text { 1964) }\end{array}$ & Alive & $\begin{array}{l}\text { Further tumour } \\
\text { R.L.L.; no } \\
\text { symptoms }\end{array}$ \\
\hline
\end{tabular}

weakness in both legs was found, with anaesthesia below the level of about the eighth thoracic segment of the spinal cord. Retention of urine soon followed. A diagnosis of metastases in the vertebral column was made, although not confirmed by radiography. His condition deteriorated and he died one month after the onset of these symptoms with progressive loss of function in the legs. At necropsy no macroscopic tumour was visible throughout the whole body; no extrathoracic primary was present. The residual lung tissue and hilar glands were normal. The vertebral bodies and brain were normal. The spinal cord was removed intact and reported on thus: On sectioning through the cord the first abnormality was noticed at T2, where there was a brownish fleck in the left anterior horn. There was in addition a whitish opaqueness of the posterior columns, especially the fasciculus of Goll, which was present at all higher levels and was no doubt due to ascending Wallerian degeneration. At $\mathrm{T} 4$ the differentiation between grey and white matter in the cord could scarcely be made out. At T9 there was an obvious central softening of the cord, which was filled with cheesy material. This became more extensive at T11, where the whole of the posterior columns were softened, and at T12 there was only a thin rim of unsoftened tissue. After L4 the cord became a little firmer, but the differentiation of cord and white matter remained indistinct until the lower sacral region.' (Dr. A. L. Woolf.)

The significance of these changes is uncertain. From the lung tissue remaining at necropsy Dr. van der Merwe removed the whole of the mucosa of the main bronchi and the residual segmental bronchi as completely as was technically possible and submitted this preparation to detailed microscopic examination. Although no significant pre-malignant changes were observed, he detected a microscopic tumour growing in and from the bronchial mucosa. There seems to be no doubt that this represented an early stage of a fourth squamous-cell primary carcinoma.

\section{DISCUSSION}

Discussion will be confined to those patients who developed a second primary tumour. In using this descriptive term it is not suggested that this mode of origin has been proved, or that disagreement would arise if it was claimed that some of the lesions have some of the features of metastases. The principal concern in this paper is the management of the patient presenting with a fresh lesion after surgery. Before discussing the practical considerations, a theoretical question which has forced itself to our notice is the effect of the removal of the first primary on the development of the second. This important aspect is discussed at length by Cole, McDonald, Roberts, and Southwick (1961). They state that 'almost all surgeons can recall patients whose tumour appeared to grow rapidly or even in an explosive fashion after operation'. Their chapters on 'The Role of Stress in the Resistance to Cancer' and 'Facts in Immunology of Cancer as Related to Dissemination' are of interest. In the field of lung cancer surgery it seems possible from our experience that more than a mechanical removal of the tumour follows resection. Its removal may inhibit the antigenic effect of this tumour, or in some other way promote dissemination of the primary or the development of a second primary. Expressed in another way, the balance that exists between host-resistance and tumour may be influenced unfavourably by resection of the primary and predispose to the development of a second or even a third primary, a hypothesis worth exploring if, in fact, a primary carcinoma of the lung of spontaneous origin in the human being has antigenic activity. 
Animal experiments were carried out by Schatten (1958) in which tumour cells were injected into the hind leg of the mouse, followed by amputation on about the twenty-first day. In 36 control mice having no amputation, lung metastases were found in $72 \%$; in 33 animals having the leg amputated, metastases were present in the lung in $100 \%$. This suggests that, by some mechanism, removing the primary by amputation decreased the animals' resistance to the cells which had desquamated from the tumour and lodged in the lungs before amputation was performed. To demonstrate that the effect was not simply due to operative trauma, the normal leg was removed in further experiments, and the same results were obtained as in the controls. Quoting this author's work, Cole et al. (1961) state that this may be interpreted as indicating that trauma had no influence on the incidence of metastases, and they agree with Schatten's suggestion that the increase in metastases is due to removal of the inhibitory effect of the tumour on metastases when the tumour is excised. They do state, however, that the problem is apparently not so simple.

The hypothesis that removal of the first primary hastens the development of a second is based on an estimate of the course of the disease if left untreated. It could be concluded that removal of the first primary allows survival long enough for the patient to develop a second primary, which would have developed regardless of treatment of the first, and further, that freedom from clinical extrathoracic metastases in these patients was a result of early detection of the original lesion. The production of apparently multiple primary tumours confined to the lung is not, however, a way in which untreated carcinoma of the lung commonly progresses.

More can be said against this hypothesis, namely, that two primaries do grow simultaneously (Britt, Christoforidis, and Andrews, 1960 ; Peterson, Pirogov, and Smulevich, 1963), and that, at the patient's death from one primary, a second is occasionally found elsewhere in the lung as a chance finding at necropsy (cases reviewed by Watson et al. (1964)). It is thus no more than an unsupported clinical impression that in some cases the patient's bronchial mucosa, predisposed to undergo malignant change, is in some way influenced to continue to produce tumours through removal of their predecessors. If this contained any element of fact, survivors from radiotherapy where the tumour's antigenic effect remains should have a significantly lower incidence of development of fresh lung primary than after resection, provided that comparable clinical cases are being compared. There is little available information on this point. We feel that the presence of attenuated tumour in the body may have an antigenic effect and that if a method of producing such diminished vitality can be established, it could be a means whereby the patient and the tumour could in some cases of lung carcinoma exist in symbiosis over a longer natural course than is at present possible. The effect is not envisaged as arising simply from the attenuation of the tumour reducing growth rate, but from the protective effect of maintained antibody in contrast to a supposed reduction in antibody which follows total resection of the primary. Nor need this effect exist in any but a very small group of tumours. Tumours suitable for lobectomy represent a small proportion of all lung carcinomata. As far as differences between tumours are concerned, we believe an oat-cell tumour and a peripheral squamous-cell tumour are as different (even though both occur in the lung) in their aetiology, management, and prognosis as two diseases of the blood such as pernicious and aplastic anaemia. To classify all lung carcinomata as one disease over-simplifies a complex problem.

INCIDENCE In discussing the total incidence of second primary carcinoma after successful lobectomy, an exact figure cannot be reached until all the patients in a series have died and the cause of death is known in each case. All that can be stated in our series is that, from 269 lobectomies carried out between 1952 and 1965, so far 19 of these patients have developed fresh primary tumours. The incidence of fresh lung primary is $6 \cdot 8 \%$. Of these 19 patients, three have developed more than two primary tumours (patients P10, $P 11$, and P12). As the remaining survivors from these 269 lobectomies die, an unknown number will die with evidence of a second primary or die from second primary tumours, and the incidence will therefore rise. Furthermore, the figure of the incidence at the time of death of the last survivor can only provide a figure of the incidence of second primary tumours which have reached the stage of clinical recognition during the life of the patient. It is apparent that fresh tumour may be present and only recognizable by a meticulous microscopic examination of the whole of the bronchial mucosa from necropsy material (case P11, Table V).

With these limitations of the accuracy of figures for total incidence exposed, our figure of $6.8 \%$ compares closely with the figure of $6.4 \%$ presented 
by Le Gal and Bauer (1961). These authors followed 63 patients who had survived lobectomy or pneumonectomy by 30 months; they encountered second primary tumours in four patients. As in our series, it is assumed that not all the survivors were followed to death. Neither group of patients was in contact with any known occupational carcinogen.

Classification of multiple primaries into synchronous or metachronous is customary. The numbers in each group depend in part on the means whereby the two tumours are discovered. The discovery of two tumours at necropsy, for instance, would warrant a description of synchronous primaries, although it does not necessarily follow that their appearance during life was simultaneous. Watson et al. (1964) collected 76 cases from the literature, and, of these, 64 were synchronous, the high incidence of cases described as synchronous being due, presumably, to a preponderance of necropsy material.

In life we have observed only three patients with synchronous primaries (none was operated upon) but 19 patients with a second primary appearing after an interval. If radiographs of the patient's chest are taken as soon as symptoms appear, or if frequent mass miniature radiography films are taken, the synchronous double primary will be seen less frequently. In case P10 (Table IV), it seems likely, had the first chest radiograph been delayed for three months, that both the lesions would have shown in the same film and the two primaries would thus have been classified as synchronous.

PaTHOLOGY The first and subsequent primary lung tumours we describe have, on the microscopic evidence, been classified by Dr. Shinton as squamous-cell tumours using the classification of Shinton (1963). The lack of agreement over histological classification is fully discussed in this author's paper. Willis (1953) discovered a heterogeneous or variable microscopic structure in $23 \%$ of necropsy specimens. Le Gal and Bauer (1961) discussed the propensity of lung cancer to show varying histological patterns in different areas of the primary. Shields et al. (1964) state that it is well known that any given bronchogenic carcinoma may present widely differing histological features in different areas of the tumour. To consider two tumours in the lung as two primary tumours on the basis of different histological features between the two could therefore be fallacious. It would also be incorrect to reject a diagnosis of two lung primary tumours because their basic histology is similar. From a study of the literature and our own experience, the histological tumour most likely to reappear in the form of a second primary is the squamous-cell tumour, although differentiation to a degree acceptable by all pathologists may not be present throughout the tumour. This being so, the patient successfully operated upon for a squamous-cell tumour is at special risk of developing a second primary.

Our information on the origin of the growth of the second primary from a point in bronchial mucosa distant from that of the first tumour is, as already stated, incomplete.

TREATMENT From the total of 19 patients with fresh lung primaries, seven patients were not operated upon a second time. Three were rejected on account of age and the others for various reasons, doubt as to the ultimate benefit from reoperation being the underlying reason behind the rejection in most cases. The histories of two patients rejected because of age demonstrate how quickly the second primary may develop and kill, even after a long interval between the first operation and diagnosis of the second primary.

CASE P13 A man, aged 62 at the time of left upper lobectomy in 1954 for a squamous-cell carcinoma with hilar gland involvement (Fig. 7), progressed satisfactorily until 1963 . He was then found to have developed a symptomless, fresh primary tumour in the right upper lobe (Fig. 8). Bronchoscopy showed contraction of the lobar bronchus but no actual tumour. He was given radiotherapy, but the lesion progressed. Deposits in the right supraclavicular glands and the signs of superior vena caval obstruction appeared within three months. He died seven months after the first radiological abnormality noted in follow-up and nine and a half years after operation.

CASE P14. A man, who had previously suffered from bilateral pulmonary tuberculosis, was aged 54 at the time of a left lower lobectomy in 1955 for a squamous-cell carcinoma (Fig. 9). He progressed satisfactorily until 1965, when a fresh, symptomless primary tumour developed in the right lower lobe (Fig. 10). The sputum contained abundant malignant cells, but no tumour was visible at bronchoscopy. The patient's condition rapidly deteriorated and he died in coma from a cerebral secondary four months after the first appearance of the second primary and 10 years after operation.

The remaining 12 patients have been operated upon again ; 10 patients have had second operations and two have been operated upon three times (Tables IV and V). 


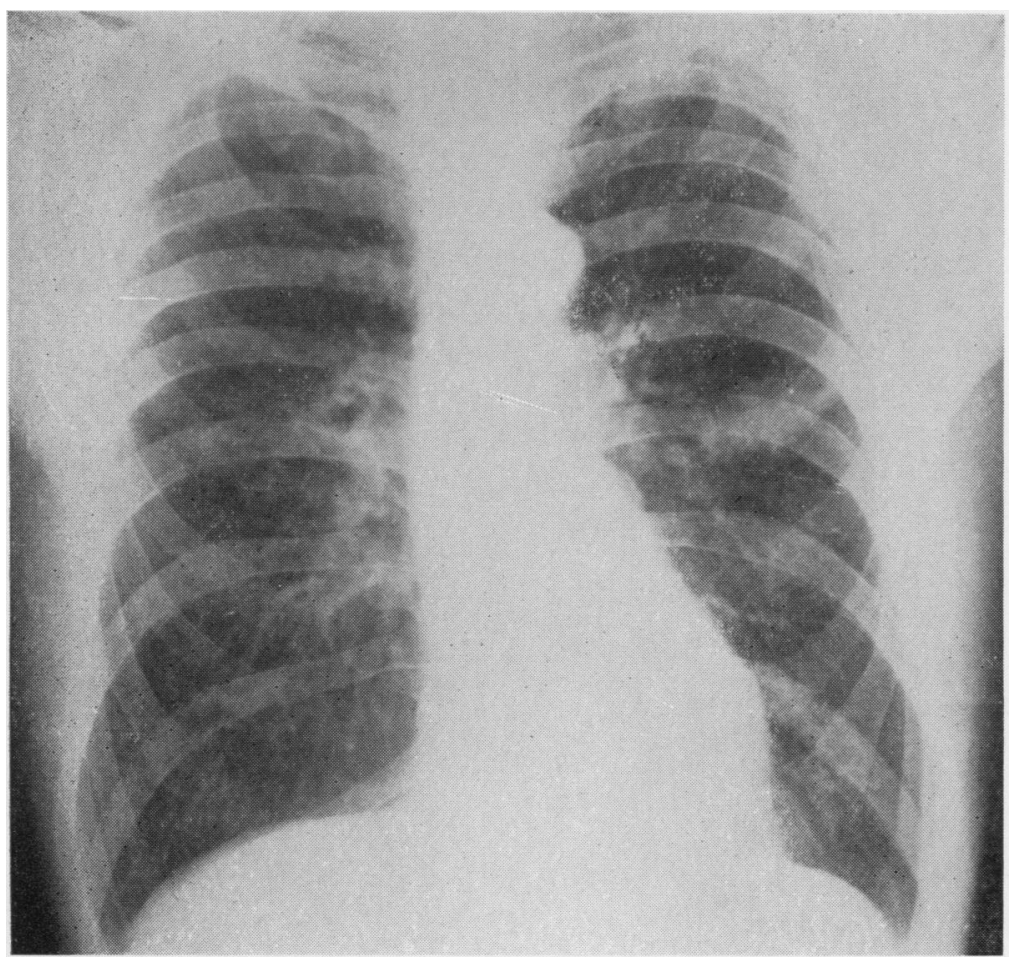

FIG. 7. Case P13, 1954, see text. Left upper lobe tumour.

FIG. 8. Case P13, 1963. Fresh primary right upper lobe, nine years after left upper lobectomy.

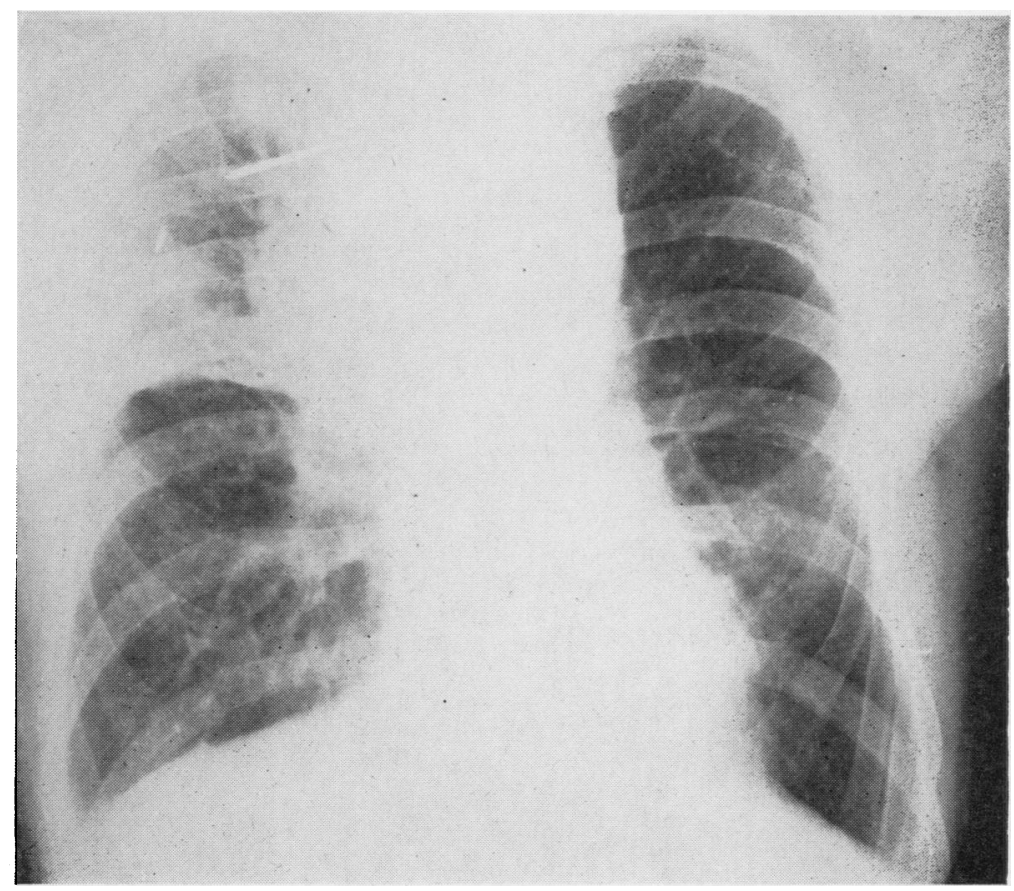




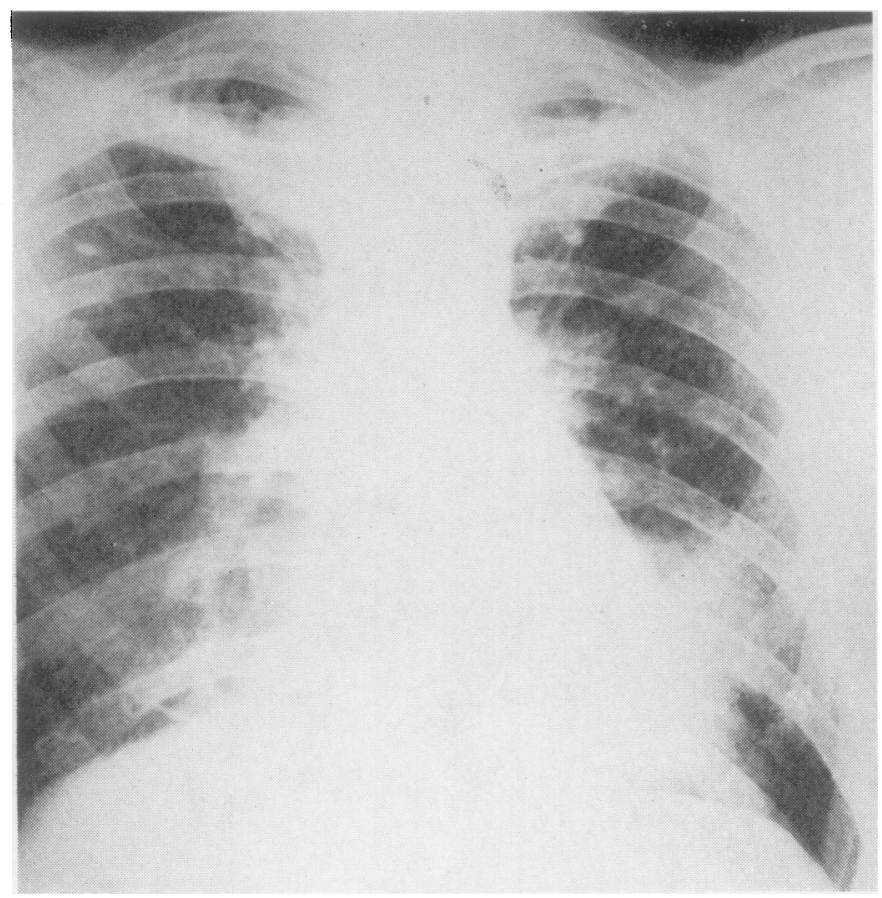

FIG. 9. Case P14, 1955, see text. Left lower lobe tumour. 


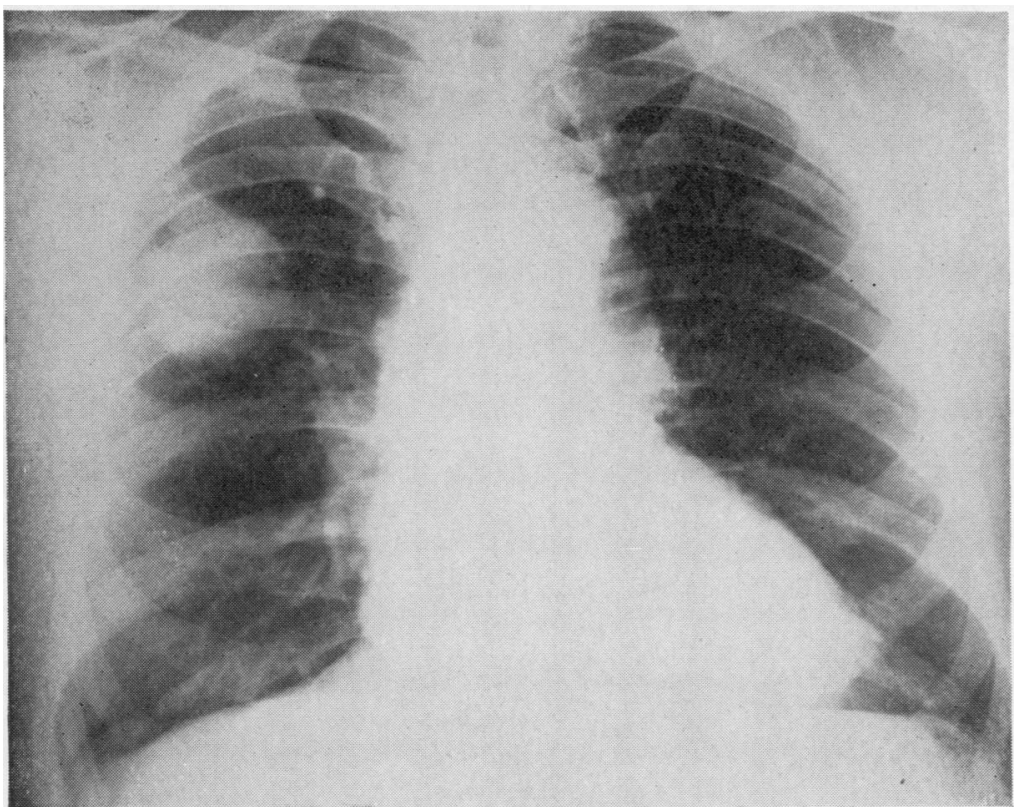

FIG. 11. Case P1, 1955 (Table IV). Right upper lobe tumour.

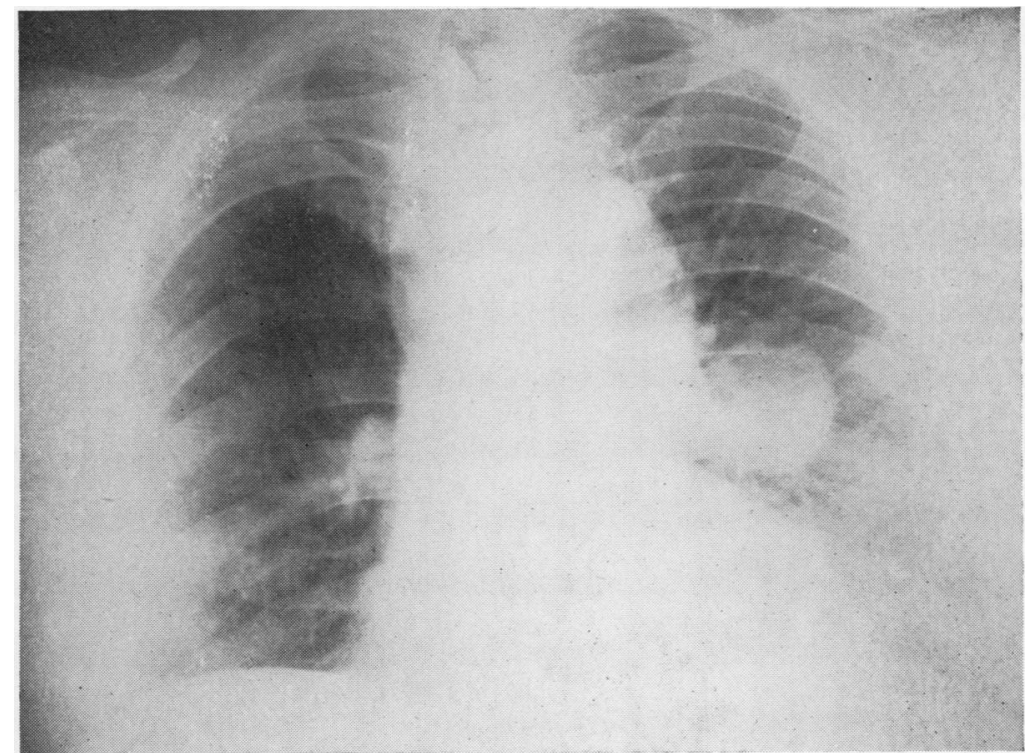

FIG. 12. Case P1, 1964. Fresh primary left lower lobe. 


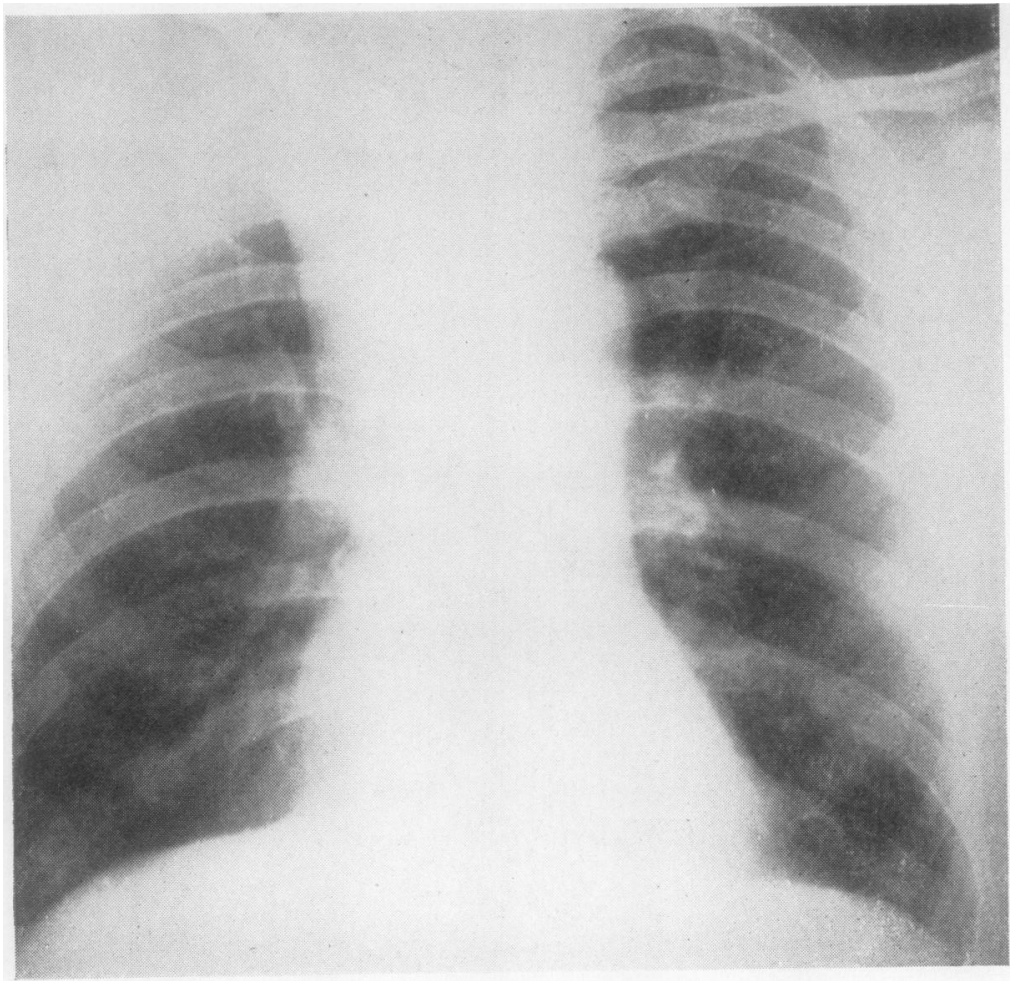

FIG. 13. Case P2, 1960 (Table IV). Right upper lobe coll apse due to tumour.

FIG. 14. Case P2, 1965. Fresh primary left lower lobe.

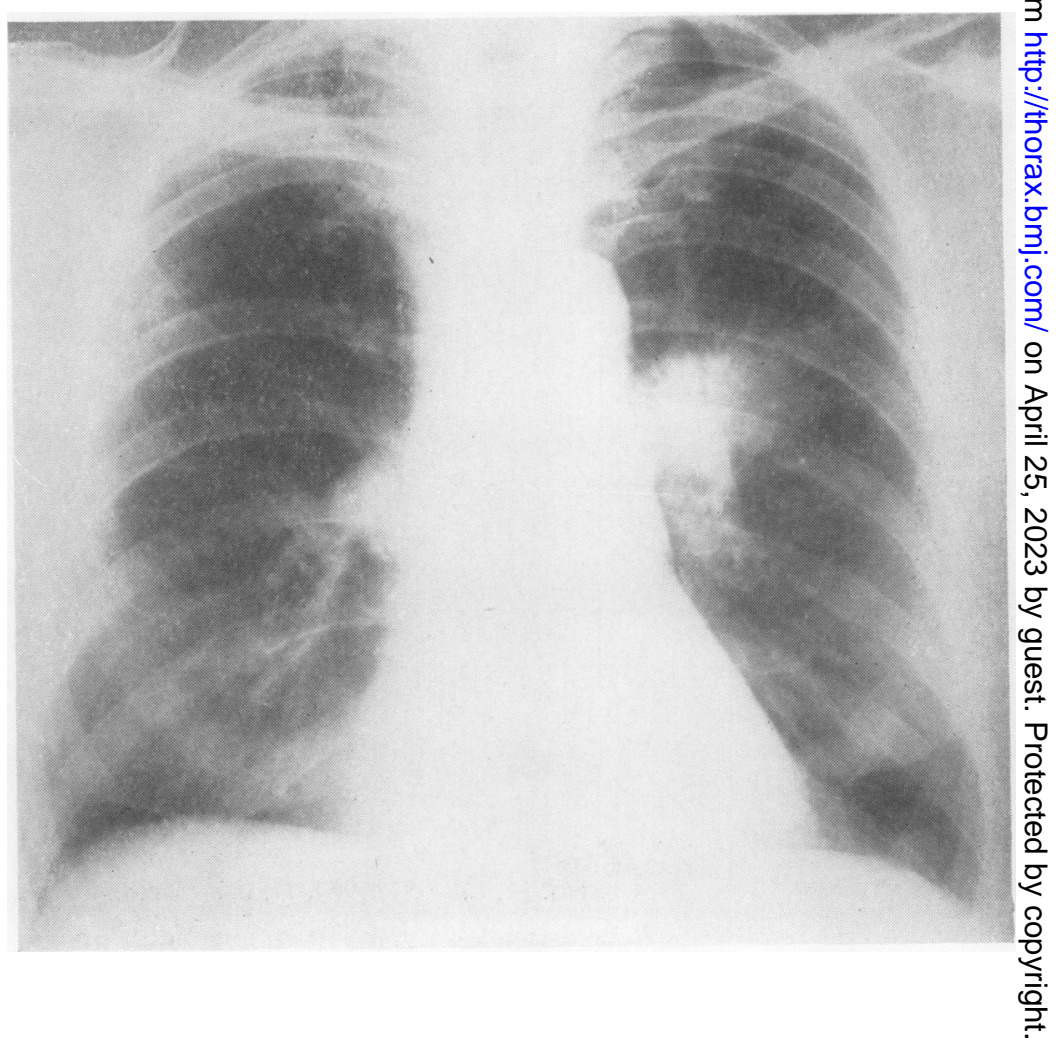




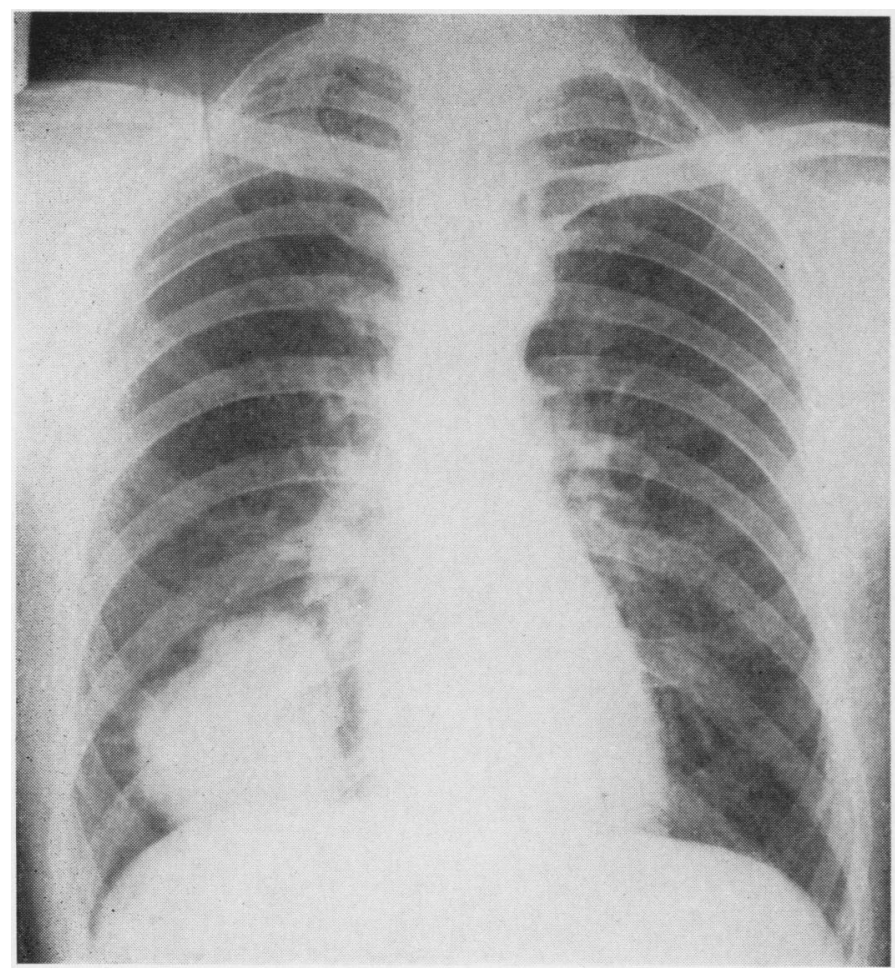

FIG. 15. Case P3, 1956 (Table IV). Right lower lobe tumour.

FIG. 16. Case P3, 1960. Fresh primary left upper lobe (confirmed by biopsy at bronchoscopy).

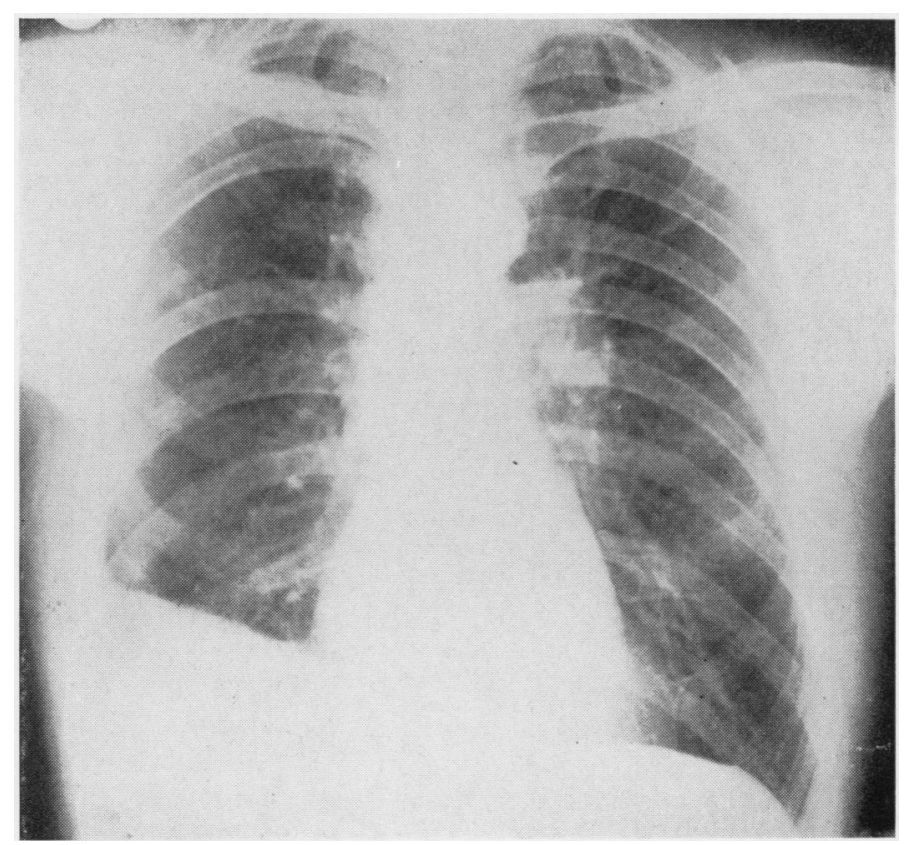




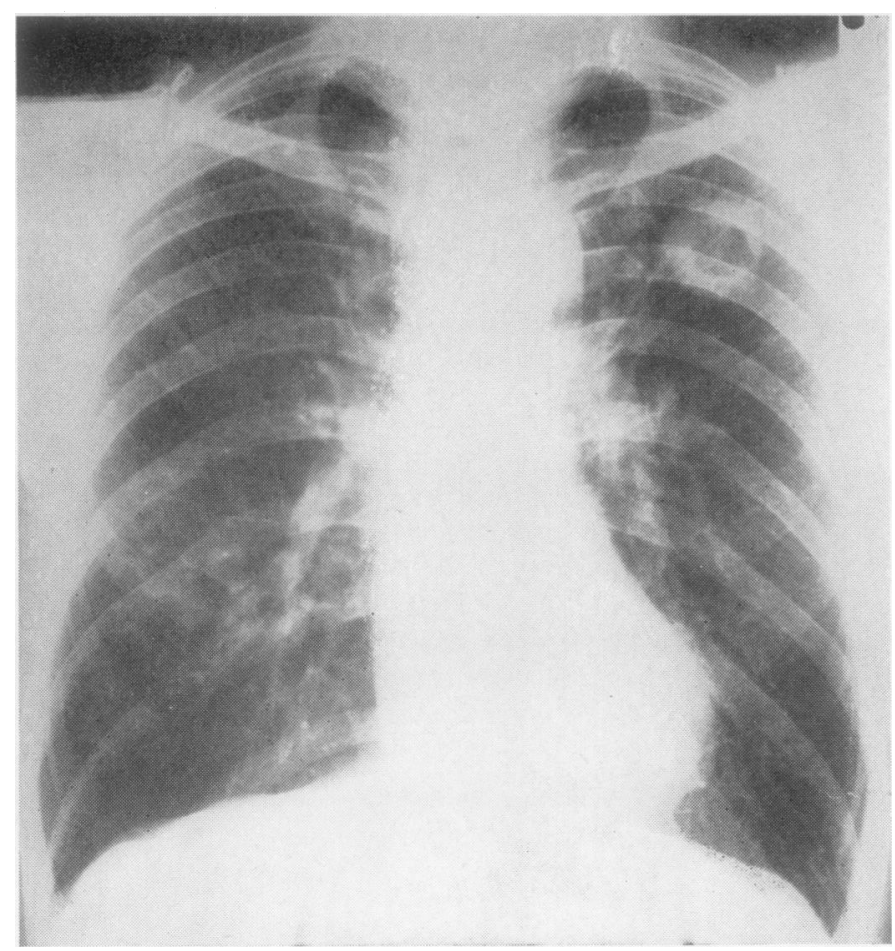

FIG. 17. Case P10, 1961 (Table IV). Left upper lobe tumour.

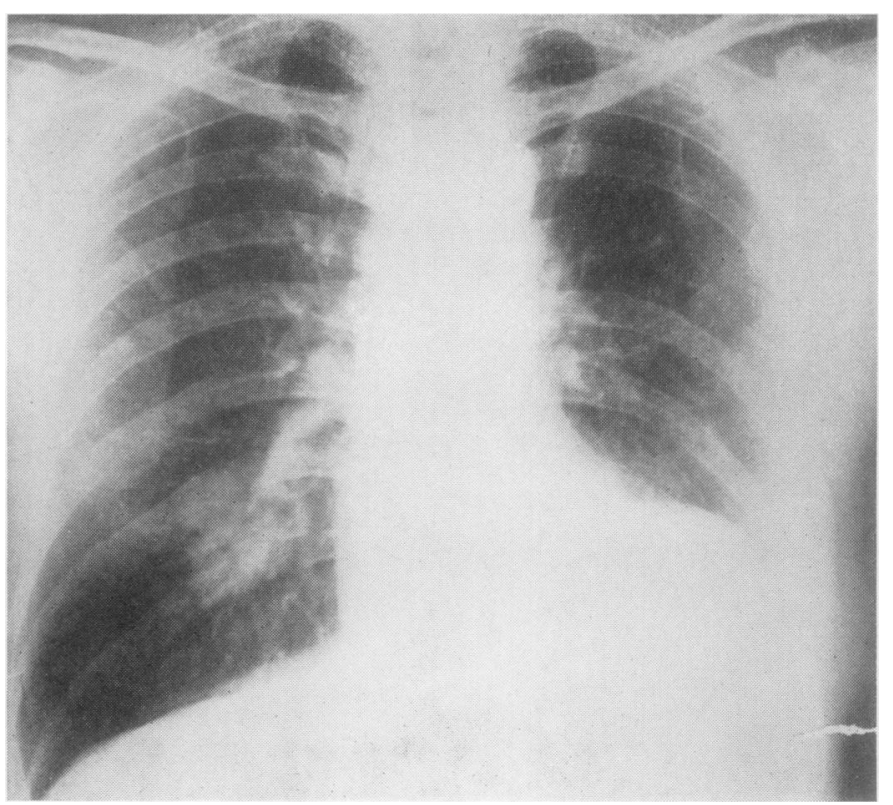

FIG. 18. Case P10. Four months after Fig. 17. Fresh primary right lower lobe. 


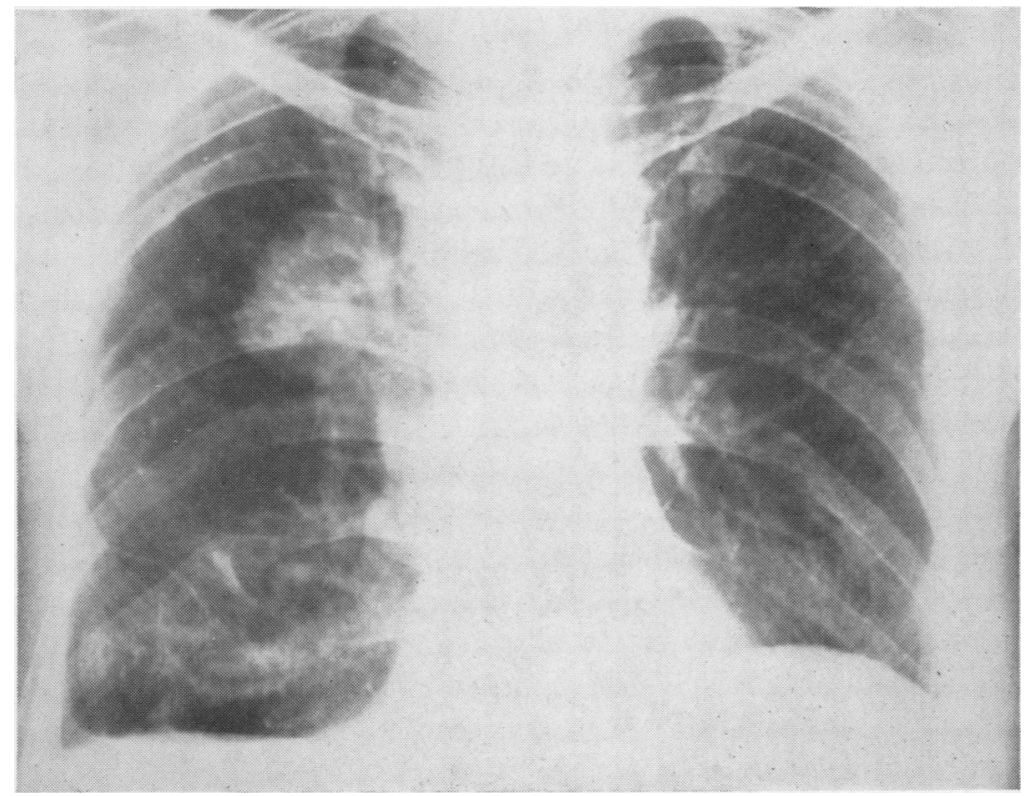

FIG. 19. Case P10, 1963. Fresh primary right upper lobe.

No patient has refused a second operation, and the tumour has been removed in each patient. No patient has been explored and the tumour found inoperable ; this can be related to early detection by frequent radiography.

The diagnosis of the neoplastic nature of the lesion, based initially on the radiographic appearances, has never been incorrect. No patient has been re-explored and a lesion other than a carcinoma found, although this might occur. The diagnosis before the second operation has been confirmed in only three of the patients by bronchoscopy. The patient's suitability for resection has been assessed by the same methods as at the original operation. No patient has died and none has been made materially worse as a result of the second operation. It is too soon to make a comparison between the results of re-operation and of treatment by some other method. The problem remains whether or not the fresh primary should be resected. Factors to be discussed must, however, have a bearing on the problem. The poor results from treatment by methods other than resection and the frequency with which a fresh primary has developed seem adequate reasons for a policy of re-operating upon the fresh primary as early as possible. It cannot be claimed that the results of re-operation are satisfactory, nor indeed could this be hoped for. The results are presented as our experience of the development and manage- ment of a second primary. The figures clearly demonstrate that the problem exists if the fresh primary is deliberately and actively sought by frequent radiography of every patient after resection. In our view this has justified the follow-up method.

Patients have already been described (cases P13 and P14) in whom the development of a second primary has quickly been fatal, but it is undoubtedly true that a patient may live in comfort for some time after successful resection with a second primary present. One patient survived two and a half years after the appearance of a second primary tumour. No means are available for deciding on the rate of progress of the second tumour; this seems to justify its removal when possible rather than to treat by other means and hope for a protracted course.

Insufficient information has come from this study to enable the patient who will develop a second primary to be recognized at the time of the first operation. The extent to which the first resection should be modified because of the possibility of having to re-operate is therefore debatable. Some heavy smokers with squamouscell carcinoma develop second primaries, but many do not. We have not thought the possibility of a second primary sufficient reason for resecting less than a lobe at the time of the first operation. In the few patients in whom evidence of carcinoma 
in situ has been sought from areas removed from the tumour in the resected specimen, no significant changes in the bronchial mucosa have been found. It seems unlikely, therefore, that worth-while evidence would consistently come from biopsy of the bronchial mucosa of the contralateral side in an attempt to establish an increased likelihood of the development of carcinoma in this lung at a later date. Had pre-malignant bronchial changes been found, more justification would exist for a conservative first operation.

One aspect of management worth mentioning is the technical difficulty of removing the left lower lobe from a patient who has previously undergone left upper lobectomy with sleeve resection of the main bronchus. Two patients have undergone this sequence (cases P4 and P12). In both patients the main pulmonary artery trunk had become fixed to the main bronchus at the line of resuture of the bronchus. At the second operation in both patients the main bronchus and pulmonary artery had to be held and divided in the same clamp. Dangerous haemorrhage occurred in identical circumstances on both occasions. In future we shall treat a second primary of this sort by radiotherapy rather than by re-operation.

The results of surgical treatment are shown in Tables IV and V.

\section{SUMMARY}

A complete post-operative radiological and clinical follow-up of 269 patients who underwent lobectomy in the period 1952 to April 1965 has been personally carried out. In 38 patients the first evidence of extension of the tumour appeared in the chest radiograph. The origin of the radiographic change is classified. Patients in whom the radiographic change was associated with generalized spread of carcinoma are excluded. Nineteen patients were considered to have developed fresh primary tumours. Treatment is discussed and the results are tabulated.
Many people have been concerned with the follow- $\stackrel{\overrightarrow{\vec{\rho}}}{\overrightarrow{3}}$ up of these patients and I am grateful to them foro their help. I am indebted to Dr. N. K. Shinton foro his classification of the tumours and to Dr. S. B $\overline{\bar{c}}$. van der Merwe for his report on an examination of the entire bronchial mucosa of patient P11. My thanks are also due to Dr. A. L. Woolf for his report on the spinal cord of the same patient.

\section{REFERENCES}

Belcher, J. R., and Anderson, R. (1965). Surgical treatment of car cinoma of the bronchus. Brit. med. J., 1,948 .

Billroth, T. (1879). Quoted by Robinson and Jackson (1958).

Britt, C. I., Christoforidis, A. J., and Andrews, N. C. (1960). Bilatera i simultaneous squamous cell carcinoma of the lung. $J$. thorac:cardiovasc. Surg., 40, 102.

Brock, R. C. (1964). Thoracic surgery: and the long-term results of operation for bronchial carcinoma. Ann. roy. Coll. Surg. Engl.o

Cliffton, E. E., das Gupta, T., and Pool, J. L. (1964). Bilatera pulmonary resection for primary or metastatic lung cancer Cancer, 17, 86.

Cole, W. H., McDonald, G. O., Roberts, S. S., and Southwick, H. W (1961). Dissemination of Cancer. Prevention and Therapy, pp. 254 and 294. Appleton-Century-Crofts, New York.

Glennie, J.S., Harvey, P. W., and Salama, V. (1964). Multiple primary carcinoma of the bronchus. A report of three cases. J. thorac $\vec{C}$ cardiovasc. Surg., 48, 40.

Goetze, O. (1913). Bemerkungen über Multiplizität primärer Car-の cinome in Aplehnung an einen Fall von dreifachen Carcinom. $Z$. Krebsforsch, 13, 281. Quoted by Watson, Cameron, and Percy (1964).

Hughes, R. K., and Blades, B. (1961). Multiple primary bronchogenic carcinoma. J. thorac. cardiovasc. Surg., 41, 421.

Langston, H. T., and Sherrick, J. C. (1962). Bilateral simultaneousd bronchogenic carcinoma. Report of a case of surgical excision. Ibid., 43, 742 .

Le Gal, Y., and Bauer, W. C. (1961). Second primary bronchogenic carcinoma. A complication of successful lung cancer surgery. Ibid., 41, 114.

Payne, W. S., Clagett, O. T., and Harrison, E. G. (1962). Surgical management of bilateral malignant lesions of the lung. Ibid., 43, 279.

Peterson, B. E., Pirogov, A. I., and Smulevich, V. B. (1963). Simultaneous bilateral lobectomy in a case of bilateral primary cancer $F$ of the lungs. Ibid., 45, 705 . Robinson, C. L. N., and Jackson, C. A. (1958). Multiple primary
cancer of the lung. J. thorac. Surg., 36, 166.

Schatten, W. E. (1958). An experimental study of postoperative tumor metastases. 1. Growth of pulmonary metastases following total removal of primary leg tumor. Cancer, 11, 455.

Shields, T. W., Drake, C. T., and Sherrick, J. C. (1964). Bilaterai primary bronchogenic carcinoma. J. thorac. cardiovasc. Surg., Shinton, N. K. (1963). The histological classification of lower respi-o
ratory tract tumours. Brit. J. Cancer, 17, 213 .

Warren, S., and Gates, O. (1932). Multiple primary malignant tumours. A survey of the literature and a statistical study. Amer. J. Cancer, 16, 1358.

Watson, A. J., Cameron, E. A., and Percy, J. S. (1964). MultipleN primary bronchial carcinoma. Report of two cases and a review. S
Brit. J. Dis. Chest, 58, 181.

Willis, R. A. (1953). Pathology of Tumours, 2nd ed., p. 368.0 Butterworth, London. 